AGRITECH, Vol. 37, No. 2, Mei 2017, Hal. 192-198

DOI: http://doi.org/10.22146/agritech.10659

ISSN 0216-0455 (Print), ISSN 2527-3825 (Online)

Tersedia online di https://jurnal.ugm.ac.id/agritech/

\title{
Isolasi dan Karakterisasi Sifat Pati Kacang Hijau (Vigna radiata L.) Beberapa Varietas Lokal Indonesia
}

\author{
Isolation and Characterization the Properties of some Indonesian Local Varieties Mung Beans (Vigna radiata) Starch
}

\author{
Priyanto Triwitono, Yustinus Marsono, Agnes Murdiati, Djagal Wiseso Marseno \\ Departemen Teknologi Pangan dan Hasil Pertanian, Fakultas Teknologi Pertanian, \\ Universitas Gadjah Mada, Jl. Flora No. 1 Bulaksumur, Yogyakarta 55281, Indonesia \\ Email: priwitono@gmail.com
}

Submisi: 15 April 2016; Penerimaan: 30 Juni 2016

\begin{abstract}
ABSTRAK
Kacang hijau merupakan jenis kacang-kacangan sumber pati beramilosa tinggi yang potensial menghasilkan RS-3 tinggi dan rendah kalori. Kajian tentang karakteristik patinya akan membuka peluang pemanfaatannya untuk penanganan obesitas di masa datang. Telah dilakukan isolasi dan karakterisasi sifat-sifat pati kacang hijau dari 4 varietas lokal Indonesia (Walet, Sriti, Murai, dan Vima-1). Isolasi pati menggunakan metode Hoover yang dimodifikasi dan sifatsifat pati yang dianalisis meliputi kadar pati, amilosa, bentuk granula, warna pati, swelling power, WHC, blue value, viskositas, dan sifat kristalinitas pati. Hasil isolasi dan analisis menunjukkan bahwa kacang hijau varietas Walet memiliki kadar amilosa paling tinggi (55,39\%), sehingga potensial sebagai bahan dasar RS-3. Kacang hijau Walet menghasilkan kadar pati 42,11\%; rendemen pati 35,33\%; kemurnian pati 99,63\%; swelling power tertinggi $17,11 \mathrm{~g} / \mathrm{g}$; WHC $65,26 \mathrm{~g} / \mathrm{g}$; OHC 59,36 g/g; Blue Value 8,92\%; bentuk granula oval; warna putih $(\mathrm{L}=88,09)$; suhu gelatinisasi $78,7^{\circ} \mathrm{C}$; pola difraksi sinar $\mathrm{X}$ tipe $\mathrm{C}$; dan viskositas pati paling cepat teretrogradasi $(1430 \mathrm{Cp})$.
\end{abstract}

Kata kunci: Amilosa; Indonesia; kacang hijau; obesitas; pati

\begin{abstract}
Mung beans is a kind of legumes that possesses a potential amylose to produce low calories RS-3. Studies on the characteristics of the starch will be useful for the treatment of obesity in the future. Isolation and characterization of the properties of mung bean starch of 4 local Indonesian varieties (Walet, Sriti, Murai, and Vima-1) have done. Isolation of starch using a modified method of Hoover. The analyzed properties of starch consist of starch content, amylose content, granular shape, color, swelling power, WHC, the blue value, amylograph and crystallinity properties. The results indicated that the mung bean varieties Walet have the highest amylose content (55.39\%), that's potential as source of RS-3. Mung beans Walet have the $42.11 \%$ of starch content; $35.33 \%$ of yield starch; $99.63 \%$ of starch purity; $17.11 \mathrm{~g} / \mathrm{g}$ of highest swelling power; $65.26 \mathrm{~g} / \mathrm{g}$ of WHC; $59.36 \mathrm{~g} / \mathrm{g}$ of OHC; $8.92 \%$ of blue value; Oval granular shape; white color (88.09 of Lightness); $78.7^{\circ} \mathrm{C}$ of gelatinization temperature; tipe $\mathrm{C}$ of X-ray diffraction pattern, and 1430 $\mathrm{Cp}$ of the fastest retrograded starch viscosity.
\end{abstract}

Keywords: Amylose; Indonesia; mung beans; obesity; starch 


\section{PENDAHULUAN}

Beberapa penelitian melaporkan bahwa kacang hijau (Vigna radiata L.) merupakan sumber amilosa yang sangat potensial. Selama pengolahan, amilosa dapat mengalami gelatinisasi dan retrogradasi sehingga menghasilkan RS-3 atau Resistant Starch Tipe 3 yang sulit dicerna dan berpengaruh baik bagi kesehatan (Stipanuk, 2000). Terbentuknya RS dipengaruhi oleh beberapa faktor antara lain sifat intrinsik dari pati alami (bentuk kristalin pati, struktur granula pati, rasio amilosa dengan amilopektin, panjang rantai amilosa). Fraksi kristalin pati yang terbentuk dipengaruhi oleh suhu dan waktu gelatinisasi dan retrogradasi (Eerlingen dan Delcour, 1995). Pati disimpan dalam granula-granula yang terpisah, dengan ukuran, bentuk, morfologi, komposisi, dan struktur molekul bervariasi tergantung asal tanamannya (Sajilata dkk., 2006). Diameter granula umumnya berkisar $1 \mu \mathrm{m}-100 \mu \mathrm{m}$, dengan berbagai variasi bentuk yang beraturan maupun yang tidak beraturan, serta terdistribusi secara tunggal maupun bergerombol (Bertolini, 2010). Pati tersusun oleh polimer rantai lurus amilosa dan polimer bercabang amilopektin. Umumnya pati mengandung $20-30 \%$ amilosa dan $70-80 \%$ amilopektin, tetapi pada varietas tertentu mengandung pati beramilopektin tingi seperti pada waxy corn dengan amilopektin 98\% (Stipanuk, 2000).

Pati kacang hijau dapat diisolasi dengan cara kering maupun cara basah, namun isolasi cara basah lebih banyak dikerjakan (Hoover dkk., 1997). Pada isolasi pati cara basah, perlu modifikasi tertentu misalnya dengan penyosohan untuk merusak sebagian kulit biji dan lembaga sehingga tidak terjadi perkecambahan selama perendaman pada suhu kamar. Kajian sifat-sifat pati kacang hijau dari berbagai negara sudah cukup banyak dilakukan, tetapi kajian sifat-sifat pati kacang hijau lokal asal Indonesia masih sangat terbatas. Sifat-sifat pati kacang hijau yang diteliti meliputi sifat fisika-kimia (kadar amilosa, swelling power, solubilitas, turbiditas, affinitas Iod/ blue value, amylose leaching, dan water holding capacity), sifat thermal (sifat gelatinisasi dan sifat retrogradasi), sifat pasta (pasting properties), dan sifat tekstur gel pati, sifat digestibilitas, sifat granula pati (bentuk dan ukuran granula pati). Penelitian ini dimaksudkan untuk menseleksi atau menentukan varietas kacang hijau lokal Indonesia yang memiliki kadar amilosa paling tinggi. Informasi sifat-sifat pati tersebut sangat penting bagi aplikasi pengembangan produk selanjutnya, antara lain pengembangan RS-3 untuk penanganan masalah obesitas.

\section{METODE PENELITIAN}

\section{Bahan}

Bahan yang digunakan adalah kacang hijau varietas lokal Indonesia (Sriti, Walet, Murai, dan Vima-1) yang diperoleh dari Balitkabi (Balai Penelitian Kacang dan Umbi) - Malang, Jawa Timur, Indonesia dan bahan-bahan kimia proanalisis (antara lain $\mathrm{NaOH}, \mathrm{HCl}$, larutan Iodin, asam asetat, larutan glukosa standard).

\section{Peralatan}

Peralatan penelitian yang digunakan antara lain blender, cabinet dryer, ayakan 80 mesh, alat-alat gelas, oven, neraca analitis, spektrofotometer UV-Vis, Scanning Electron Microscope (SEM), X-Ray Diffraction (XRD), Rapid Visco Analyzer (RVA).

\section{Cara Penelitian}

Isolasi atau Ekstraksi pati kacang hijau dilakukan dengan metode Hoover (1997) yang dimodifikasi. Biji kacang hijau disosoh selama 1 menit, kemudian direndam akuades 1:3 (b/b) selama 3 jam, dan selanjutnya kulit luar dipisahkan. Keping biji yang telah bersih dari kulit selanjutnya digiling halus, diekstraksi dan disaring. Pati dicuci dengan $\mathrm{NaOH} 0,1$ M sampai pH 9,0 untuk deproteinasi, kemudian pati dibiarkan mengendap, dan dipisahkan serta dikeringkan. Deproteinasi dilakukan beberapa kali dan pada tahapan akhir dilakukan penetralan dengan $\mathrm{HCl} 0,1 \mathrm{~N}$.

\section{Metode Analisis}

Analisis kadar air (metode Thermogravimetri, AOAC 1990); kadar pati (metode hidrolisis asam, AOAC 1990); kadar amilosa (metode Juliano, 1971); analisis swelling power (metode Takashi dan Sieb, 1988); water holding capacity/WHC (metode Yamazaki, 1953); analisis kompleks amylose-iod atau blue value (metode Birch dan Priestley, 1973); perubahan struktur pati (SEM/Scanning Electron Microscope); warna (Chromameter, Hunter System); sifat pasta/rheology (Rapid Visco Analyzer); sifat kristalinitas granula pati (XRD - X Ray Diffraction).

\section{Analisis Statistik}

Analisis statitisk menggunakan Analisis Varians (Anova) dengan program SPSS 17.0. Tingkat perbedaan ditentukan dengan Duncan Multiple Range Test (DMRT) pada level signifikan 5\% $(p<0,05)$.

\section{HASIL DAN PEMBAHASAN}

\section{Komposisi Pati Kacang Hijau dan Rendemennya}

Kacang-kacangan dikenal sebagai bahan pangan sumber protein, namun pada kacang hijau mempunyai sifat cukup unik. Kacang hijau mengandung protein dan sekaligus pati cukup tinggi (Tabel 1). Di negara Cina, kacang hijau mengandung kadar pati 54,73\%-57,99\% (Wenhao 
Li dkk., 2011) dan banyak dimanfaatkan sebagai bahan baku produk olahan berbasis pati, seperti mie, soun dan vermicelli. Perbedaan komposisi antara varietas kacang hijau lokal Indonesia dengan kacang hijau di luar negeri tersebut dimungkinkan karena perbedaan varietas, iklim, unsur hara tanah serta daerah asal tempat tumbuhnya (Asaoka dkk., 1985; Morrison dan Azudin, 1987; Anonim, 2012).

Meskipun kadar patinya cukup tinggi, tetapi besarnya rendemen pati yang mampu diekstraksi bervariasi. Kacang hijau varietas Sriti mempunyai rendemen tertinggi (36,76\%), sedangkan rendemen terendah varietas Vima-1 (29,49\%). Dari beberapa penelitian terdahulu dilaporkan rendemen kacang hijau sebesar 31,1\% (Hoover dkk., 1997), sebesar $34,5 \%$ (Naivikul dan D'appolonia, 1979), dan sebesar 26\% dari kacang hijau utuh serta $30,5 \%$ dari kacang hijau kupas kulit (Abdel-Rahman dkk., 2008). Beberapa faktor yang berpengaruh terhadap hasil rendemen tersebut antara lain metode ekstraksi, frekuensi deproteinasi, tingkat kebersihan penghilangan kulit, dan teknik pemisahan residu dari endapan pati. Selain itu kemungkinan juga disebabkan oleh perbedaan varietas, iklim, unsur hara tanah serta daerah asal tempat tumbuhnya (Asaoka dkk., 1985; Morrison dan Azudin, 1987). Informasi rendemen ini sangat penting sebagai gambaran seberapa jauh effisiensi ekstraksi pati kacang hijau, misalnya untuk dimanfaatkan sebagai bahan baku industri pengolahan pangan atau industri farmasi.

\section{Kemurnian Pati dan Kadar Amilosa}

Kemurnian pati menggambarkan prosentase kadar pati dalam pati hasil ekstraksi. Cukup tingginya bahan-bahan lain dalam ekstraksi pati seperti abu dan lemak, akan menurunkan kadar RS-3 yang dihasilkan (Sajilata dkk., 2006) sehingga perlu dianalisis kandungannya. Hasil analisis kemurnian pati dan kadar amilosa kacang hijau lokal Indonesia disajikan pada Tabel 2. Hasil ekstraksi pati kacang hijau mempunyai kemurnian pati sangat tinggi (berkisar 99,22 - 99,80\%) dengan kadar abu dan lemak sangat rendah. Kemurnian pati semua varietas tidak berbeda nyata. Amilosa adalah bahan dasar RS3 , sehingga kadar amilosa yang tinggi akan menghasilkan
Tabel 2. Kemurnian pati dan kadar amilosa kacang hijau beberapa varietas lokal Indonesia

\begin{tabular}{lccccc}
\hline Varietas & $\begin{array}{c}\text { Air } \\
\% \mathrm{bb}\end{array}$ & $\begin{array}{c}\text { Abu } \\
\% \mathrm{bk}\end{array}$ & $\begin{array}{c}\text { Lemak } \\
\% \mathrm{bk}\end{array}$ & $\begin{array}{c}\text { Kemurnian } \\
\text { pati }^{*}, \% \mathrm{bk}\end{array}$ & $\begin{array}{c}\text { Amilosa } \\
\% \mathrm{bk}\end{array}$ \\
\hline Murai & $13,94^{\mathrm{a}}$ & $0,18^{\mathrm{a}}$ & $0,01^{\mathrm{a}}$ & $99,77^{\mathrm{a}}$ & $54,22^{\mathrm{a}}$ \\
Sriti & $14,53^{\mathrm{b}}$ & $0,18^{\mathrm{a}}$ & $0,01^{\mathrm{a}}$ & $99,22^{\mathrm{a}}$ & $54,42^{\mathrm{a}}$ \\
Vima-1 & $12,71^{\mathrm{c}}$ & $0,11^{\mathrm{b}}$ & $0,01^{\mathrm{a}}$ & $99,80^{\mathrm{a}}$ & $53,70^{\mathrm{a}}$ \\
Walet & $14,84^{\mathrm{d}}$ & $0,17^{\mathrm{a}}$ & $0,01^{\mathrm{a}}$ & $99,63^{\mathrm{a}}$ & $55,39^{\mathrm{b}}$ \\
\hline
\end{tabular}

*) Kemurnian pati = kadar pati dari hasil ekstraksi pati.

Superscript yang berbeda dalam satu kolom menunjukkan ada perbedaan signifikan $(p<0,05)$.

kadar RS-3 yang tinggi pula. Kadar amilosa tertinggi adalah varietas Walet $(55,39 \% \mathrm{bk})$.

Beberapa penelitian melaporkan kadar amilosa kacang hijau asal Cina sebesar 40,44 - 41,82\% (Wenhao-Li dkk., 2011), kacang hijau asal Kanada sebesar $45,3 \%$ (Hoover dkk., 1997), kacang hijau asal Korea sebesar 39,7 - 42,2\% (Sun-Jin Park dkk., 2012), dan kacang hijau asal Virginia sebesar 33,6 - 37,9\% (Yixiang Xu dkk., 2012). Menurut Juliano (1971), kadar amilosa 10 - 20\% dikategorikan rendah, $20-25 \%$ dikategorikan sedang, dan $25-30 \%$ dikategorikan tinggi. Hasil penelitian ini membuktikan bahwa kadar amilosa pati kacang hijau lokal Indonesia termasuk sangat tinggi dan posisinya tidak kalah dengan amilosa kacang hijau dari negara lain, bahkan lebih tinggi kandungannya.

\section{Sifat Swelling Power (SP), Water Holding Capacity (WHC), Oil Holding Capacity (OHC), dan Blue Value (BV)}

Sifat Water Holding Capacity (WHC), Swelling Power, OHC dan Blue Value (BV) Amilosa Pati Kacang Hijau Lokal Indonesia disajikan pada Tabel 3. Swelling power atau kemampuan pembengkakan pati merupakan parameter yang menjelaskan kemampuan penyerapan air selama proses gelatinisasi pati. Kemampuan tersebut terjadi karena adanya gugus hidroksil pada molekul pati, sehingga pati bersifat hidrofilik atau mudah mengikat air. Kemampuan

Tabel 1. Komposisi kacang hijau varietas lokal Indonesia dan rendemen patinya

\begin{tabular}{lccccccc}
\hline \multicolumn{1}{c}{ Varietas } & $\begin{array}{c}\text { Air } \\
\% \mathrm{bb}\end{array}$ & $\begin{array}{c}\text { Protein } \\
\% \mathrm{bk}\end{array}$ & $\begin{array}{c}\text { Lemak } \\
\% \mathrm{bk}\end{array}$ & $\begin{array}{c}\text { Abu } \\
\% \mathrm{bk}\end{array}$ & $\begin{array}{c}\text { Karbohidrat } \\
\% \mathrm{bk}\end{array}$ & $\begin{array}{c}\text { Pati } \\
\% \mathrm{bk}\end{array}$ & $\begin{array}{c}\text { Rendemen*) } \\
\%\end{array}$ \\
\hline Murai & $11,91^{\mathrm{a}}$ & $19,34^{\mathrm{a}}$ & $0,83^{\mathrm{a}}$ & $3,81^{\mathrm{a}}$ & $64,11^{\mathrm{a}}$ & $43,46^{\mathrm{a}}$ & $34,81^{\mathrm{a}}$ \\
Sriti & $11,70^{\mathrm{b}}$ & $18,83^{\mathrm{b}}$ & $1,09^{\mathrm{b}}$ & $3,54^{\mathrm{b}}$ & $64,84^{\mathrm{b}}$ & $40,52^{\mathrm{b}}$ & $36,76^{\mathrm{a}}$ \\
Vima-1 & $11,47^{\mathrm{c}}$ & $20,79^{\mathrm{c}}$ & $0,69^{\mathrm{c}}$ & $3,58^{\mathrm{b}}$ & $63,46^{\mathrm{c}}$ & $40,41^{\mathrm{b}}$ & $29,49^{\mathrm{b}}$ \\
Walet & $11,89^{\mathrm{a}}$ & $20,06^{\mathrm{d}}$ & $0,71^{\mathrm{c}}$ & $3,65^{\mathrm{b}}$ & $63,69^{\mathrm{c}}$ & $42,11^{\mathrm{c}}$ & $35,33^{\mathrm{a}}$ \\
\hline
\end{tabular}

Superscript yang berbeda dalam satu kolom menunjukkan ada perbedaan signifikan $(p<0,05)$.

*) Rendemen $=($ berat pati terekstrak / berat sampel kacang hijau) $\times 100 \%$ 
pembengkakan pati dipengaruhi oleh suhu pemanasan. Bila pati dipanaskan pada suhu $>55^{\circ} \mathrm{C}$ dalam air berlebih maka granula pati akan menyerap air, kemudian membengkak, dan pada akhirnya pecah. Pada suhu gelatinisasi (sekitar $70{ }^{\circ} \mathrm{C}$ ) tingkat pembengkakannya masih terbatas dan masih bersifat reversibel, namun bila pemanasan ini diteruskan maka granula pati akan membengkak lebih besar sampai pada akhirnya pecah (irreversible). Parameter swelling power ini diukur pada suhu $85^{\circ} \mathrm{C}$ sehingga pengukuran pada suhu tersebut sudah melampai suhu gelatinisasinya dan bersifat irreversibel.

Kemampuan swelling power dipengaruhi oleh kadar amilosa (Singh dkk., 2006). Semakin tinggi kadar amilosa, berarti semakin banyak gugus hidrofil dan makin banyak air yang terikat, sehingga swelling power-nya makin besar. Dalam penelitian ini (Tabel 3), terdapat kecenderungan korelasi antara swelling power dan kadar amilosanya. Kacang hijau varietas Walet mempunyai swelling power dan kadar amilosa tertinggi, berturut-turut $17,11 \mathrm{~g} / \mathrm{g}$ dan 55,39\% bk.

Kemampuan swelling power diduga juga dipengaruhi oleh ukuran granula. Granula pati yang berukuran besar, mempunyai makna ukuran molekul pati yang terkandung juga besar, sehingga memungkinkan air yang terikat lebih banyak dan swelling powernya besar. Swelling power yang tinggi menunjukkan kemampuan pati mengembang dalam air semakin besar, sehingga dalam aplikasi pengolahan pangan berbasis pati dapat dipergunakan untuk memperkirakan volume wadah yang akan digunakan.

Sifat WHC dan OHC menunjukkan kecenderungan yang sejalan atau paralel, namun kemampuan WHC sedikit lebih besar daripada OHC (Tabel 3). Diduga hal ini berhubungan dengan sifat afinitas air dan minyak yang berbeda terhadap gugus hidroksil pati. Air bersifat hidrofilik sehingga dapat berikatan dengan gugus hidroksil pati, sebaliknya minyak bersifat lipofilik sehingga tidak berikatan dengan gugus hidroksil pati dan hanya terperangkap dalam massa pati saja.

Blue Value (BV) atau pembentukan kompleks amilosa-

Tabel 3. Sifat WHC, Swelling power, OHC, dan blue value pati alami kacang hijau beberapa varietas lokal Indonesia

\begin{tabular}{lcccc}
\hline Varietas & $\begin{array}{c}\text { Swelling } \\
\text { power }(\mathrm{g} / \mathrm{g})\end{array}$ & $\begin{array}{c}\text { WHC } \\
(\%)\end{array}$ & $\begin{array}{c}\text { OHC } \\
(\%)\end{array}$ & $\begin{array}{c}\text { Blue value } \\
(\%)\end{array}$ \\
\hline Murai & $14,60^{\mathrm{a}}$ & $75,17^{\mathrm{a}}$ & $65,84^{\mathrm{a}}$ & $6,12^{\mathrm{a}}$ \\
Sriti & $14,33^{\mathrm{a}}$ & $68,78^{\mathrm{b}}$ & $60,91^{\mathrm{b}}$ & $7,81^{\mathrm{b}}$ \\
Vima-1 & $14,69^{\mathrm{a}}$ & $63,88^{\mathrm{c}}$ & $55,47^{\mathrm{b}}$ & $5,83^{\mathrm{a}}$ \\
Walet & $17,11^{\mathrm{b}}$ & $65,26^{\mathrm{c}}$ & $59,36^{\mathrm{c}}$ & $8,92^{\mathrm{c}}$ \\
\hline
\end{tabular}

Superscript yang berbeda dalam satu kolom menunjukkan ada perbedaan signifikan $(p<0,05)$.
Iodine warna biru merupakan salah satu parameter untuk mengukur derajat geltinisasi pati berdasarkan kolorimetri. Metode ini dikembangkan berdasarkan prinsip bahwa selama proses gelatinisasi pati, amiosa akan dibebaskan dan amilosa yang terlarut dapat membentuk kompleks warna biru dengan Iodine (Birch dan Priestley, 1973). Oleh karena itu parameter ini secara tidak langsung dapat dipergunakan sebagai indikator potensi amilosa pada pati. Makin besar nilai Blue Value berarti makin besar pula kompleks amilosa-Iod yang terbentuk. Dalam penelitian ini, pati kacang hijau Walet mempunyai Blue Value paling besar (Tabel 3).

\section{Warna}

Hasilpengukuran warna patialami dengan Chromameter disajikan pada Tabel 4. Pati alami mempunyai warna putih dengan intensitas derajat putih atau kecerahan yang berbedabeda. Derajat putih pati kacang hijau lokal Indonesia berkisar antara 86,09 - 89,41. Kacang hijau Murai mempunyai derajat putih paling rendah dibandingkan dengan derajat putih ketiga varietas lainnya (Sriti, Vima-1, dan Walet) yang mempunyai derajat putih tidak berbeda nyata. Parameter a dengan nilai negatif menunjukkan adanya peningkatan intensitas warna hijau, dan parameter $\mathrm{b}$ dengan nilai positip menunjukkan peningkatan intensitas warna kuning.

Tabel 4. Warna pati alami kacang hijau beberapa varietas lokal Indonesia

\begin{tabular}{lccc}
\hline \multicolumn{1}{c}{ Varietas } & $\mathrm{L}$ & $\mathrm{a}$ & $\mathrm{B}$ \\
\hline Murai & $86,09^{\mathbf{a}}$ & $-0,90^{\mathbf{a}}$ & $2,51^{\mathbf{a}}$ \\
Sriti & $89,41^{\mathbf{b}}$ & $-0,71^{\mathbf{b}}$ & $2,22^{\mathbf{b}}$ \\
Vima-1 & $88,33^{\mathbf{b}}$ & $-0,91^{\mathbf{a}}$ & $2,59^{\mathbf{a}}$ \\
Walet & $88,09^{\mathbf{b}}$ & $-0,69^{\mathbf{b}}$ & $1,99^{\mathbf{b}}$ \\
\hline L = Derajat putih ; a = Nilai merah-hijau ; b = Nilai kuning-biru \\
\hline \multicolumn{4}{c}{ Superscript yang berbeda dalam satu kolom menunjukkan ada perbedaan } \\
\multicolumn{4}{c}{ signifikan $(p<0,05)$} \\
\hline
\end{tabular}

\section{Sifat Viskoamilografi}

Perilaku sifat amilografi pati alami kacang hijau yang diukur dengan RVA dapat dilihat pada Tabel 5. Awal terjadinya gelatinisasi pati tidak selalu sama, tergantung sumber patinya. Meskipun dalam hal ini bahannya sama yaitu pati alami kacang hijau, akan tetapi awal gelatinisasi terjadi pada menit yang berbeda yaitu pada menit ke 11,12 dan 14 pada suhu yang berbeda berturut-turut $67,3{ }^{\circ} \mathrm{C} ; 67,5^{\circ} \mathrm{C} ; 71,1$ ${ }^{\circ} \mathrm{C}$; dan $78,7^{\circ} \mathrm{C}$ (varietas Murai, Sriti, Vima-1 dan Walet).

Selama pemanasan, granula pati menyerap air dan membengkak sampai titik tertentu, sampai pada akhirnya pecah. Amilosa dalam granula pati akan dibebaskan (Eliasson, 1985; Tester dan Morrison 1990), dan selanjutnya suspensi 
Tabel 5. Sifat viskoamilografi pati alami kacang hijau lokal Indonesia

\begin{tabular}{lccccccc}
\hline \multirow{2}{*}{ Varietas } & \multicolumn{2}{c}{ Awal gelatinisasi } & \multicolumn{3}{c}{ Granula pati pecah } & \multicolumn{2}{c}{ Viskositas } \\
\cline { 2 - 7 } & Waktu (menit) & Suhu $\left({ }^{\circ} \mathrm{C}\right)$ & Waktu (menit) & Suhu $\left({ }^{\circ} \mathrm{C}\right)$ & Viskositas $(\mathrm{Cp})$ & $50\left({ }^{\circ} \mathrm{C}\right)$ & Balik $(\mathrm{Cp})$ \\
\hline Murai & 11 & 67,3 & 16 & 85,3 & 3045 & 4790 & 1745 \\
Sriti & 11 & 67,5 & 15 & 82,6 & 2720 & 4440 & 1720 \\
Vima-1 & 12 & 71,1 & 20 & 94,2 & 2285 & 4735 & 2450 \\
Walet & 14 & 78,7 & 20 & 94,2 & 2290 & 3721 & 1431 \\
\hline
\end{tabular}

pati cair akan membentuk pasta atau jaringan tiga dimensi dengan viskositas tertentu bila mengalami gelatinisasi, dan akan membentuk gel bila konsentrasi pati cukup tinggi dan membentuk pati retrogradasi bila mengalami pendinginan (Miles dkk., 1985). Gambaran tersebut terlihat seperti pola viskoamilografi dengan RVA (rapid visco analyzer) (Gambar 1).

Berdasarkan klasifikasi tipe kurva amilografi menurut Schoch dan Maywald (1968), pati alami kacang hijau lokal Indonesia mempunyai dua macam tipe yaitu tipe B (varietas Murai dan Sriti) dan tipe C (varietas Vima-1 dan Walet). Kurva amilografi pati alami kacang hijau varietas Murai dan Sriti menunjukkan adanya puncak viskositas kemudian mengalami sedikit penurunan (ciri khas pati tipe B). Sebaliknya pada kacang hijau varietas Vima-1 dan Walet tidak menunjukkan puncak seperti pada tipe A maupun tipe $\mathrm{B}$, dan mempunyai viskositas sangat tinggi yang konstan atau naik saat pemasakan, sehingga dikategorikan pati tipe $\mathrm{C}$.

Sifat amylografi pati yang penting terkait dengan RS adalah viskositas balik, yaitu selisih antara viskositas akhir setelah pendinginan suhu $50{ }^{\circ} \mathrm{C}$ dengan viskositas panas atau maksimum setelah pemanasan suhu $95^{\circ} \mathrm{C}$. Viskositas balik adalah viskositas yang menggambarkan kecenderungan pasta pati mengalami retrogradasi setelah pendinginan. Dari Tabel 5 terlihat bahwa viskositas pati kacang hijau yang paling

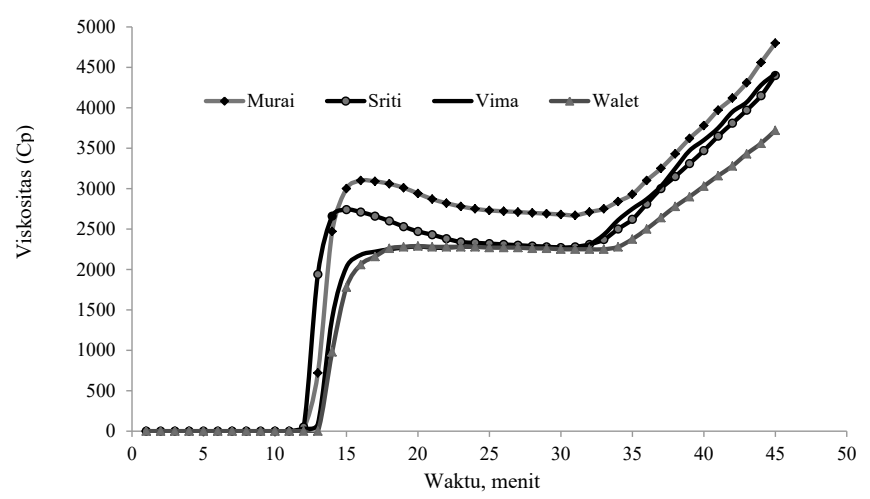

Gambar 1. Viskoamilograf pati alami kacang hijau beberapa varietas lokal Indonesia dengan RVA (rapid visco analyzer) cepat teretrogradasi adalah pati kacang hijau varietas Walet (1430 Cp). Kecenderungan terjadinya retrodegradasi yang meningkat selama pendinginan disebabkan karena selama proses pemanasan terjadi pemecahan granula sehingga jumlah amilosa yang dibebaskan semakin banyak dan mendorong terjadinya retrogradasi pada saat pendinginan (BeMiller dan Huber, 2007). Viskositas akhir yang paling tinggi adalah kacang hijau varietas Murai, sedangkan yang paling rendah adalah varietas Walet.

\section{Bentuk dan Ukuran Granula Pati}

Granula pati kacang hijau mempunyai bentuk dan ukuran tidak seragam serta sangat heterogen. Granula pati kacang hijau berbentuk oval sampai bulat, seperti ginjal (kidneyshaped), elips, bulat-kecil, dan berbentuk kubah dengan ukuran granula antara 5 - $40 \mu \mathrm{m}$ (Wenhao-Li dkk., 2011). Menurut Hoover dkk. (1997) pati kacang hijau mempunyai bentuk granula oval dengan ukuran diameter 7-16 $\mu \mathrm{m}$.

Bentuk dan ukuran granula pati alami beberapa varietas kacang hijau lokal Indonesia yang diamati dengan SEM (Scanning Electron Microscope) disajikan pada Gambar 2. Bentuk granula pati alami kacang hijau lokal Indonesia adalah elips seperti ginjal dan mempunyai permukaan halus dengan ukuran granula yaitu diameter atau lebar (L) 9,05 - 21,08 $\mu \mathrm{m}$ dan panjang (P) 12,67 - 31,07 $\mu \mathrm{m}$. Meskipun parameter ukuran granula tidak mampu menjelaskan kandungan amilosa ataupun amilopektin atau rasio keduanya, namun ukuran granula pati secara sepintas bisa menggambarkan kandungan pati secara keseluruhan. Hal ini karena granula merupakan kantung yang berisi butiran-butiran pati.

\section{Pola Difraksi Sinar X (X-Ray Diffraction)}

Pengujian pola spectrum diffraksi sinar X (X-Ray Diffraction) dimaksudkan untuk mengetahui tipe kristalinitas dari pati. Spektrum pola diffraksi sinar X pati alami kacang hijau lokal Indonesia disajikan pada Gambar 3.

Pati alami kacang hijau berbagai varietas lokal Indonesia mempunyai pola spektrum diffraksi sinar $\mathrm{X}$ yang serupa. Menurut Cai dan Wei (2013), ada beberapa pola diffraksi sinar $\mathrm{X}$ dari pati. Pola XRD tipe A mempunyai puncak difraksi kuat 


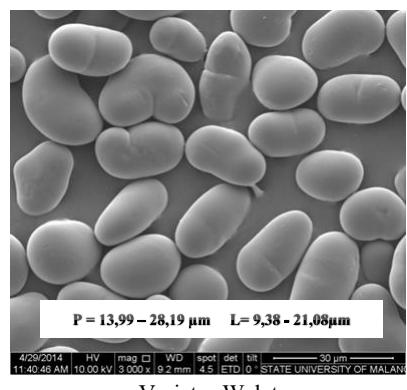

Varietas Walet

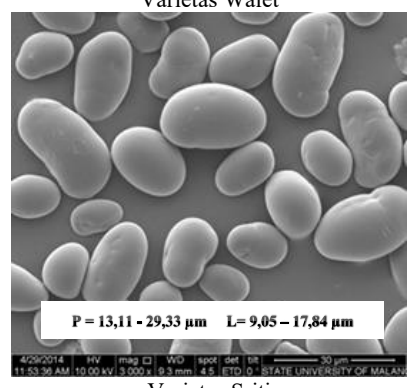

Varietas Sriti

Bentuk dan ukuran granula pati alami kacang hijau beberapa varietas lokal Indonesia yang diamati dengan SEM Perbesaran $3000 \mathrm{X}$

sekitar $15^{\circ}$ dan $23^{\circ}$, serta puncak yang tidak sempurna sekitar $17^{\circ}$ dan $18^{\circ}$. Pola XRD tipe B memiliki puncak difraksi terkuat di sekitar $17^{\circ}$, serta beberapa puncak kecil di sekitar $15^{\circ}, 20^{\circ}, 22^{\circ}$, dan $24^{\circ}$, dan puncak khusus pada $5,6^{\circ}$. Pola $\mathrm{XRD}$ tipe $\mathrm{C}$ mempunyai sifat campuran dari tipe A dan tipe B. Pola khas XRD tipe $\mathrm{C}$ mempunyai puncak terkuat sekitar $17^{\circ}$ dan $23^{\circ}$, serta beberapa puncak kecil sekitar $5,6^{\circ}$ dan $15^{\circ}$. Berdasarkan pola diffraksi yang ditunjukkan pada Gambar 2 dapat disimpulkan bahwa pola difraksi sinar X pati alami kacang hijau adalah tipe $\mathrm{C}$, sebab puncak terkuat terjadi pada $17^{\circ}$ dan $23^{\circ}$, serta puncak kecil pada $15^{\circ}$.

Meskipun tipe pola diffraksinya sama tetapi intensitas sinar $\mathrm{X}$ (luas area atau tinggi puncak atau peak amylograph) terlihat berbeda. Diduga perbedaan intensitas

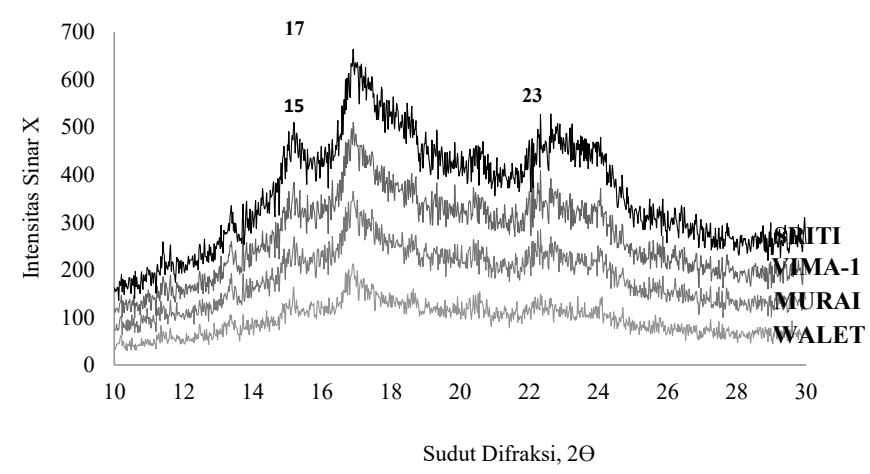

Gambar 3. Pola spektrum XRD pati alami kacang hijau beberapa varietas lokal Indonesia tersebut berhubungan erat dengan sifat kristalinitas dari masing-masing pati (kadar amilosa dan amilopektin). Pati merupakan bahan semikristalin yang mengandung daerah kristal dan amorf. Daerah kristalin sebagian besar terdiri dari amilopektin, sedangkan daerah amorf terdiri dari amilosa dan titik percabangan amilopektin (Ratnayake dan Jackson, 2006). Hal ini menjelaskan bila kadar amilosa tinggi menunjukkan daerah kristalnya makin rendah tetapi daerah amorfnya paling tinggi. Berdasarkan Gambar 3, kacang hijau varietas Walet mempunyai intensitas atau derajat kristalinitas paling rendah sebab kadar amilosanya paling tinggi (Tabel 2).

\section{KESIMPULAN}

Di antara keempat varietas kacang hijau yang dianalisis, hasil isolasi dan analisis menunjukkan bahwa kacang hijau varietas Walet memiliki kadar amilosa paling tinggi (55,39\%) sehingga berpotensi besar sebagai bahan dasar RS-3 rendah kalori. Kacang hijau Walet menghasilkan kadar pati 42,11\%, rendemen pati $35,33 \%$, kemurnian pati 99,63\%; swelling power tertinggi 17,11 g/g; WHC $65,26 \mathrm{~g} / \mathrm{g}$; OHC 59,36 $\mathrm{g} / \mathrm{g}$; blue value $8,92 \%$; bentuk granula Oval; warna putih $(\mathrm{L}=88,09)$; suhu gelatinisasi $78,7{ }^{\circ} \mathrm{C}$; pola difraksi sinar $\mathrm{X}$ tipe $\mathrm{C}$, dan mempunyai viskositas balik yang paling cepat teretrogradasi (1430 Cp).

\section{DAFTAR PUSTAKA}

Abdel-Rahman, S.A., El-Fishawy, F.A., El-Geddawy, M.A. dan Kurz, T. (2008). Isolation and physico-chemical characterization of mung bean starches. International Journal of Food Engineering 4(1): 1556-3758.

Anonim (2012). PedomanTeknis Pengelolaan Produksi Kacang Tanah, Kacang Hijau dan Aneka Kacang 2012. Direktorat Budidaya Aneka Kacang dan Umbi, Ditjen Tanaman Pangan Kementrian Pertanian, Jakarta.

AOAC. (1990). Official Methods of Analysis. 15 th $\mathrm{ed}$, Arlington, Virginia: Association of Official Analytical Chemists.

Asaoka, M., Okuno, K. dan Fuwa, H. (1985). Effect of environmental temperature at the milky state on amylose content and fine structure of waxy and nonwaxy endosperm starches of rice (Oryza sativa L.). Agricultural and Biological Chemistry 49: 373-376.

BeMiller, J.N. dan Huber, K.C. (2007). Carbohydrates. Dalam: Srinivasan, D., Parkin, K.L dan Fennema, O.R. (ed.). Food Cemistry. CRC Press, Boca Raton, FL. 
Bertolini, A.C. (2010). Starches: Characterization, Properties, and Applications. CRC Press. Boca Raton, London New York.

Birch, G.G. dan Priestley, R.J. (1973). Degree of gelatinisation of cooked rice. Starch 25: 98-100.

Cai, C.H. dan Wei, C.X. (2013). In situ observation of crystallinity disruption patterns during starch gelatinization. Carbohydrate Polymers 92: 469-478.

Eerlingen, R.C. dan Delcour, J.A. (1995). Formation, analysis, structure and properties of type III enzyme resistant starch. Journal of Cereal Science 22: 129-138.

Eliasson, A.C. (1985). Starch gelatinization in the presence of emulsifiers: A morphological study. Starch/Staerke 37: 411.

Hoover, R., Li, Y.X., Hynes, G. dan Senanayake, N. (1997). Physicochemical characterization of mung bean starch. Food Hydrocolloids 11: 401-408.

Juliano, B.O. (1971). A simplified assay for milled rice amylose. Cereal Science Today 16: 334-340.

Miles, M.J., Morris, V.J. dan Ring, S.G. (1985). Gelation of amylose. Carbohydrate Research 135: 257.

Morrison, W.R. dan Azudin, M.N. (1987). Variation in the amylose and lipid contents and some physical properties of rice starches. Journal of Cereal Science 5: 35-37.

Naivikul, O. dan D'appolonia, B.L. (1979). Carbohydrates of legume flours compared to wheat flour: II. Starches. Cereal Chemistry 56(1): 24-28.

Ratnayake, W.S dan Jackson, D.S. (2006). Gelatinization and solubility of corn starch during heating in excess water: new insights. Journal of Agricultural Food Chemistry 54: 3712-3716.

Sajilata, M.G., Singhal, R.S. dan Kulkarni, P.R. (2006). Resistant starch - a review. Comprehensive Reviews in Food Science and Food Safety 5: 1-17.
Schoch, T.J. dan Maywald E.C. (1968). Preparation and properties of various legume starches. Cereal Chemistry 45: 564-573.

Singh, J., McCarthy, O.J. dan Singh, H. (2006). Physicochemical and morphological characteristics of New Zealand Taewa (Maori potato) starches. Carbohydrate Polymers 64: 569-581,

Stipanuk, M.H. (2000). Biochemical and Physiological Aspect of Human Nutrition. W.B. Saunders Companny, Toronto.

Sun-Jin Park, Eun-Ok Choe, Jung-In Kim dan Malshick Shin (2012). Physicochemical properties of mung bean starches in different Korean varieties and their gel textures. Food Science Biotechnology 21(5): 13591365 .

Takashi, S. dan Seib, P.A. (1988): Paste and gel properties of prime corn and wheat starches with and without native lipids. Journal of Cereal Chemistry 65: 474-480.

Tester, R.F. dan Morrison, W.R. (1990). Swelling and gelatinization of cereal starches. I. Effects of amylopectin, amylose and lipids. Cereal Chemistry 67: 551.

Wenhao Li, Chang Shu, Peili Zhang dan Qun Shen (2011). Properties of starch separated from ten mung bean varieties and seeds processing characteristics. Food Bioprocess Technology 4: 814-821.

Yamazaki, W.T. (1953). An alkaline water retention capacity test for the evaluation of cookie baking potentialities of soft winter wheat flours. Cereal Chemistry 30: 242-246.

Yixiang Xu, E. N. Sismour, S. S. Narina, D. Dean, H.L. Bhardwaj dan Zhenxing Li (2012). Composition and properties of starches from Virginia-grown kabuli chickpea (Cicer arietinum L.) cultivars. International Journal of Food Science and Technology 